\title{
religion .

\section{Mermaids and Spirit Spouses: Rituals as Technologies of Gender in Transnational African Pentecostal Spaces}

\author{
JEANNE REY*
}

\begin{abstract}
This article aims to approach the construction of gender in transnational spaces by focusing on the ritual practice of African Pentecostal migrants in Europe and in Africa. One dimension of African Pentecostalism is its insistence on the practice of exorcism called 'deliverance' where malevolent spirits are expelled from one's body. Within the Pentecostal demonology, several categories of spirits carry implications for how gender is constructed. This article will analyse effects of the appearance of these spirits on the construction of gender among Ghanaian and Congolese Pentecostal churches in Geneva and in Accra. It will show that variations in the appearance of spirits within rituals can be interpreted as a negotiation of gender roles in a migratory context. Shifts in Pentecostal demonology can therefore be interpreted as a response to the reconfiguration of gender roles associated with the broader gender context and work opportunities in Europe.
\end{abstract}

\section{Key words}

Pentecostalism, gender technologies, ritual, transnationalism, Geneva, Accra.

\section{Author affiliation}

Jeanne Rey holds a Doctorate in Anthropology and Sociology from the Graduate Institute of International and Development Studies in Geneva. She is a Researcher at the Department of Anthropology and Sociology at the Graduate Institute of International and Development Studies in Geneva and at the University of Teacher Education in Fribourg. Her field of research includes anthropology of religion, rituals, migration, mobility and education. In particular, she is interested in religious practices among the African diaspora and in migration and Pentecostalism.

\footnotetext{
*Correspondence: Anthropology and Sociology Department, Graduate Institute of International and Development Studies, Case postale 136, CH 1211 Genève 21, Switzerland, E-mail: jeanne.rey-pellissier@graduateinstitute.ch This work is licensed under a Creative Commons Attribution License (3.0)
} Religion and Gender | ISSN: 1878-5417 | www.religionandgender.org | Igitur publishing 


\section{Introduction}

On a Friday night, in the multicultural urban area of Les Pâquis at the centre of Geneva, about one hundred migrants from several countries - mostly Africa, but also from Asia, Latin America and sometimes Europe - are gathered in the main room of the Church for the Nations, a Pentecostal church led by an Indian pastor who formerly worked with the United Nations. The preacher for the day is a Ghanaian pastor who had come especially from Accra. The evening prayer is attended mainly by women, most of them active members of the church. The congregation stands on both sides of the room, so that the central space remains free to perform the ritual practices. As usual, Friday night is dedicated to 'prayer and deliverance', the latter being a ritual practice whereby spirits are expelled from one's body through a 'powerful' prayer by a 'man of God'. After an hour or so of preaching, the Ghanaian pastor interrupts his talk explaining that he would like to treat a very specific problem. He introduces the topic to the international audience by pointing to its 'African' dimension: 'Let me be African!' Some people, he says, might have the impression to have sexual intercourse with an extra-marital partner. That could be the sign of a 'marriage in the spirit' with a demon. Marriages in the spirit might occur to both men and women and they are responsible for relationship problems, sterility and persisting single life. A European female listener, who seems unfamiliar with the problem explained, asks for more information. The Ghanaian pastor specifies that spirit marriages occur in dreams, not in 'reality'. After that presentation, he suggests that people concerned with that kind of problem should come to him for prayer. About ten people approach the 'man of God' who lays his hands on their heads, commanding the spirit to leave them. Most of them fall on the ground, which is perceived as a sign of a successful deliverance.

This scene was observed in one of the biggest Pentecostal church founded and attended by migrants in Geneva. ${ }^{1}$ The scene offers an example of how ritual practices develop within transnational spaces. The non-African church attendants, who were already familiar with deliverance practices, were presented a new category of spirit that is causing troubles related to several aspects of the gendered life (like marital relationships or fertility). The spirit, however, is already well known to those who attend African Pentecostal churches as the so-called 'spirit spouse'. This figure is one of the most widely spread category of spirits in West and Central African Pentecostalism. By contrast, European Pentecostals are unfamiliar with this particular category of spirit. ${ }^{2}$ Their introduction to a European audience raises therefore the question of the transnationalization of spirits in Pentecostal spaces.

1 J. Rey, 'A la conquête des Nations (Unies): millénarisme, combat spirituel et internationalisation' in S. Fancello and A. Mary (eds.), Chrétiens africains en Europe. Prophétismes, pentecôtismes et politique des nations, Paris: Karthala 2010, 351-379.

2 However, similar entities could be found in Europe in the Roman and Medieval times, which are known as 'incubus' (male demon) and 'succubus' (female demon). They also had sexual intercourse with their victim. 


\section{Gender Construction Within Transnational Spaces}

The development of transnational spaces where the nation-state no longer functions as a 'container of social, economic and political processes'. ${ }^{3}$ opens new grounds for the study of migration processes that do not exclusively focus on the integration of immigrants. Though transnationalism cannot be considered as a new phenomenon, the expansion of travel and communication facilities offers new possibilities for the development of transnational social spaces. ${ }^{4}$ Thus, these transnational spaces contain different social processes including the circulation of persons, information or goods, but also imaginaries, ritual practices and identification processes. Whenever people migrate, they generally carry their own ritual practices as well as the 'entities' that might be associated with them, so that 'the spirits that travel with them are as much a part of the complex processes of globalization as the migrants themselves'. ${ }^{5}$ This is certainly the case with Pentecostalism, where spirits take part in the migration process.

One process that might be influenced by transnationalism is the construction of gender. Differing local gender configurations might coexist within transnational spaces. Thus, conflicts around gender roles might arise, whenever conflicting gender configurations meet in transnational spaces. James Clifford points to this dialectic of gender: 'On the one hand, maintaining connections with homelands, with kinship networks, and with religious and cultural traditions may renew patriarchal structures. On the other, new roles and demands, new political spaces, are opened by diaspora interactions'. ${ }^{6}$ Migration and transnationalism can thus lead to a negotiation of gender roles $^{7}$ or to their new distribution in both the transnational and the local context.

In this article, I address the question of the role of ritual practice in the construction of gender in a migratory context. This study will focus on Pentecostalism, which is frequently associated with transnationality. ${ }^{8}$ Pentecostal and Charismatic Churches (PCCS) in Africa often insist on taking part in a global world and developing transnational connections:

'What is distinctly new about PCCs is their propagation of the Prosperity Gospel and their strong global inclination. Their names, which often refer to the church's aspired 'international' or 'global' (out)reach, highlight PCCs' aim to develop and

3 S. Vertovec, 'Transnationalism and Identity' in Journal of Ethnic and Migration Studies 27:4 (2001), 573-582: 575.

4 L. Pries, 'Configurations of Geographic and Societal Spaces: a Sociological Proposal Between 'Methodological Nationalism' and the 'Spaces of Flows' ' in Global Networks 5:2 (2005), 167-190.

5 G. Hüwelmeier and K. Krause, 'Introduction' in G. Hüwelmeier and K. Krause (eds.), Traveling Spirits: Migrants, Markets, and Mobilities, London and New York: Routledge 2009, 1-16: 9.

6 J. Clifford, 'Diasporas' in Cultural Anthropology 9:3 (1994), 302-338: 313-314.

7 J. Dahinden, 'Contesting Transnationalism? Lessons from the Study of Albanian Migration Networks from Former Yugoslavia' in Global Networks 5:2 (2005), 191-208.

8 A. Corten and R. Marshall-Fratani, 'Introduction' in A. Corten and R. Marshall-Fratani (eds.), Between Babel and Pentecost: Transnational Pentecostalism in Africa and Latin America, Bloomington: Indiana University Press 2001, 1-21. 
maintain international branches in other African countries and the West, and to deploy notions of identity and belonging that deliberately reach beyond Africa'. ${ }^{9}$

In the last decades, and in particular during the last fifteen years, this claim to transnationality has found a new expression in Europe, where African migrants established branches of Pentecostal churches that often maintained connections with African denominations. These social spaces that span across borders also constitute a new place for (re-)constructing gender roles.

In the first part of this article, I will briefly describe the context of the creation of Pentecostal churches by African migrants in the Lake Geneva urban area. I will then elaborate on how rituals might be approached as a 'technology of gender'. In the next section, I will analyse Pentecostal deliverance practices and will describe the main features of some spirits who are directly involved in the construction of gender in Pentecostal African churches. Finally, I will discuss the implications of the presence of these spirits on the construction of gender and will assess how shifts in the ritual practice can be associated with a reconfiguration of gender roles in a migratory context.

\section{African Pentecostal Migrants in the Lake Geneva Region}

The flow of African migrants to Geneva and other cities in Switzerland has started in the 1960s, following the gradual independence of African states from their former colonial rulers. During the first two decades, African migration to Switzerland was mainly composed of diplomats, international civil servants and students who belonged to their countries' social and economic elite. At that time, migration was always conceived as temporary and aimed at gaining education or developing a career. ${ }^{10}$ From 1980 onwards, several events led to major changes in African migrations: political crises and the failure of development politics together with the increase of foreign debt have led many African countries to structural adjustment programmes and economic recession. During this period, the first asylum seekers arrived to Switzerland from Zaire or Angola. Migrations from Africa increased in the following decade: wars and the further deterioration of African states have led to a growing flow of asylum seekers from Central and East Africa. More recently, migrations from West Africa has also increased including from regions where Pentecostalism tends to play a major role in the urban life, like Ghana or Nigeria.

9 B. Meyer, 'Christianity in Africa: From African Independent to Pentecostal-Charismatic Churches' in Annual Review of Anthropology 33 (2004), 447-474: 453. While several authors stress that the growing popularity of Pentecostal and Charismatic churches in Africa is associated with this claim to open the doors of the 'global', 'modern' world, it is also attributed to the failure of the post-colonial nation state, the rise of neo-liberalism, the mediatisation of popular culture or the aspirations of young generations to overcome gerontocratic structures (for a review on these issues, see Meyer, Ibid.).

$10 \mathrm{~J}$. Bagalwa Mapatano, Crise de l'Etat et migrations: La diaspora congolaise-zaïroise en Suisse 1980-2005 Paris: Publibook 2007; J. Bagalwa Mapatano, 'Les réseaux diasporiques africains de Suisse entre 'intégrationnisme' et transnationalisme' in A. Manço and C. Bolzman (eds.), Transnationalités et développement: rôles de l'interculturel, Paris: L'Harmattan 2010, 59-70.

Religion and Gender vol. 3, no. 1 (2013), pp. 60-75 
While early attempts at founding churches were made in the 1980s, the majority of African-led Charismatic-Pentecostal churches in Switzerland were founded from the 1990s onwards. In 2009, the Centre intercantonal d'Informations sur les Croyances reported over sixty 'foreign evangelical churches' in the city of Geneva alone. Among these, the majority are either Charismatic or Pentecostal. They are historically linked to the broader movement of churches from the South spreading into European cities from the 1970s onwards, a phenomenon which has been increasing over the last two decades. ${ }^{11}$ In Geneva, half of these churches were founded by Africans, mainly from the Democratic Republic of the Congo (DRC) or Ghana. Most African churches are located in the French-speaking part of the country, especially in the urban regions around Lake Geneva. This reflects the fact that migrants from Sub-Saharan Africa live mainly in urban French-speaking regions around Lake Geneva. ${ }^{12}$ In 2009, the Federation of Protestant Churches in Switzerland estimated the number of 'new migrant churches' at about 300 for the whole country..$^{13}$ They observed that African churches generally organize into French-speaking and Englishspeaking churches and that the national heterogeneity of the members tends to increase with time.

Today, Congolese constitute one of the biggest populations of Sub-Saharan migrants in Switzerland. ${ }^{14}$ From the 1960 s to the mid-1980s, Congolese migrants were mainly children of civil servants under the Mobutu regime who came to study at a Swiss university before returning to their home country. ${ }^{15}$ Those temporary migrants established neither churches nor networks based on religious affiliation. In the late 1980s and during the 1990s, as a result of economic and political changes that had led to instability in the DRC, an increasing number of migrants came to Switzerland. Many of them no longer considered their migration as temporary and most of them hoped for a better future in Europe. This situation coincides with the first wave of churches founded in Switzerland by people from Congo. Some years later, a network of African churches (the Conférence des Eglises Africaines en Suisse) was established - most of which were French-speaking churches led by Congolese pastors - and by the year 2000 Congolese migrants had established churches in every Swiss city.

Ghanaian migrants are about four times fewer than Congolese in Switzerland. Their migration to Switzerland is partly linked to a reorientation of migration flows to Europe from traditional destinations (like the Netherlands) due to

\footnotetext{
11 See e.g. M. Bergunder and J. Haustein, Migration und Identität: Pfingstlichcharismatische Migrationsgemeinden in Deutschland, Frankfurt am Main: Lembeck 2006; A. Adogame, R. Gerloff and K. Hock, Christianity in Africa and the African Diaspora, London: Continuum 2008; S. Fancello and A. Mary, Chrétiens africains en Europe: Prophétismes, pentecôtismes et politiques des nations, Paris: Karthala 2010.

12 OFS, La population étrangère en Suisse, Neuchâtel: Office Fédéral de la Statistique 2007; D. Efionayi-Mäder, M. Pecoraro and I. Steiner, La population sub-saharienne en Suisse: un aperçu démographique et socio-professionnel, Neuchatel: Forum Suisse pour l'étude des migrations et de la population, Université de Neuchâtel 2011.

13 S. Röthlisberger and M.D. Wüthrich, Les nouvelles Eglises de migrants en Suisse, Berne: Editions Fédération des Eglises protestantes de Suisse FEPS 2009.

${ }^{14}$ Only Erithreans and Somalis are more numerous (Efionayi-Mäder et al. 2011).

15 Bagalwa Mapatano, 2007, op. cit.
} 
increased restrictions in migration policies. Around 14,000 visas (annual permit or permanent residence) have been granted by the Swiss Embassy in Ghana between 1973 and $2003,{ }^{16}$ while it is estimated that only 1400 Ghanaians lived in Switzerland in 2009. ${ }^{17}$ This gives evidence for a strong circulation among Ghanaians, whose migration to Switzerland is usually temporary. English-speaking churches were founded in Switzerland by Ghanaian pastors since the late 1990s. They attract migrants from Nigeria, Ghana but also from West African Frenchspeaking countries, as they sometimes translate their services into French (especially in the French-speaking part of Switzerland). Some churches are also attended by (non-migrants) Swiss citizens.

\section{Rituals as Technologies of Gender}

In this article, I suggest to consider Pentecostal deliverance ritual practices as 'technologies of gender' that contribute to construct, reinforce or transform gender and gender roles. While using an ethnographic method to describe the process of gender construction, I will analyse ritual practices as 'technologies', thereby following an approach inspired by Michel Foucault's ${ }^{18}$ 'genealogy' which aims at producing 'an analysis which can account for the constitution of the subject within a historical framework'. ${ }^{19}$ According to Foucault, 'technologies' may include discourses, procedures and knowledge which are deeply involved in the constitution of the subject. Teresa de Laurentis developed these conceptual premises and suggested the concept of 'technologies of gender'20 where gender becomes the product of various social technologies (like cinema, institutional discourses or epistemologies). Following this approach, ritual practices can thus be apprehended as technologies of gender as far as they convey assumptions about gender and contribute to its construction.

Ritual practices involve an embodied dimension that reinforces their performative effect on gender construction. In the case of African Pentecostal ritual practices, prayer and deliverance often imply the embodiment of spiritual entities that are valued positively (the Holy Spirit) or negatively (other spirits, also referred to as 'demons'). The latter are supposed to be expelled during ritual

\footnotetext{
${ }^{16}$ K.A. Twum-Baah, 'Volume and Characteristics of International Ghanaian Migration' in T. Manuh (ed.), At Home in the World? International Migration and Development in Contemporary Ghana and West Africa, Accra: Sub-Saharan Publishers 2005, 55-77.

17 Efionayi-Mäder, et al., 2011, op. cit.

${ }_{18}$ M. Foucault, 'Pourquoi étudier le pouvoir: la question du sujet,' in Hubert Dreyfus and Paul Rabinow (eds.), Michel Foucault. Un parcours philosophique, Paris: Gallimard 1984, 297-308; M. Foucault, 'Truth and Power' in Paul Rabinow (ed.), The Foucault Reader: An introduction to Foucault's Thought, With Major New Unpublished Material, New York: Pantheon Books 1984, 51-75; M. Foucault, L'herméneutique du sujet, Paris: Gallimard 2001.

${ }^{19}$ Foucault, 'Truth and Power', 59.

20 T. de Lauretis, Technologies of Gender: Essays on Theory, Film, and Fiction, London: Macmillan Press 1989.
} 
practices called 'deliverance'. ${ }^{21}$ It consists of a prayer of exorcism whereby the possessed person might enter a state of trance in which the spirit manifests itself. ${ }^{22}$ In this analysis, I will not look for possible causes of spirit possession. ${ }^{23}$ Rather, I will focus on the effects of spirit possession and on what it does (e.g. on its performative dimension) on gender. The concept of technology of gender is thereby helpful, because it considers gender as the product of ritual practices and points to the processes of gender construction.

Pentecostalism has already been approached as a 'technology', inspired by Foucault's approach. In particular, the concept of 'technology of the self' has been applied to Pentecostal practices. ${ }^{24}$ Foucault defined technologies of the self as technologies

'which permit individuals to effect by their own means or with the help of others a certain number of operations on their own bodies and souls, thoughts, conduct, and way of being, so as to transform themselves in order to attain a certain state of happiness, purity, wisdom, perfection, or immortality.' ${ }^{25}$

While this definition applies to some aspects of Pentecostal practices, ${ }^{26}$ it is not always sufficient for analysing possession by spirits and deliverance practices. Indeed, these practices imply 'objectifying' (making into an object) possessed people rather than 'subjectifying' (making into a subject) them: ${ }^{27}$ during the deliverance ritual, the possessed person is often expected to remain passive and is sometimes explicitly asked not to pray - while the pastor is praying and

${ }^{21}$ P. Gifford, 'The Complex Provenance of Some Elements of African Pentecostal Theology' in A. Corten and R. Marshall-Fratani (eds.), Between Babel and Pentecost: Transnational Pentecostalism in Africa and Latin America, Bloomington and Indianapolis: Indiana University Press 2001, 62-79.

22 This topic is also discussed by other authors in this special issue, see Duffuor and Harris and Silva and Rodrigues.

${ }^{23}$ Causes of spirit possession are often of central importance in approaches which consider spirit possession as an exception or as an anomaly to be explained. On this issue, see M. Lambek, 'Traveling Spirits. Unconcealment and Undisplacement' in G. Hüwelmeier and K. Krause (eds.), Traveling Spirits: Migrants, Markets, and Mobilities, London and New York: Routledge 2009, 17-35.

${ }^{24}$ R. van Dijk, 'Time and Transcultural Technologies of the Self in the Ghanaian Pentecostal Diaspora' in A. Corten and R. Marshall-Fratani (eds.), Between Babel and Pentecost: Transnational Pentecostalism in Africa and Latin America, Bloomington: Indiana University Press 2001, 216-234; R. Marshall, Political Spiritualities: The Pentecostal Revolution in Nigeria, Chicago, London: The University of Chicago Press 2009.

${ }^{25}$ Michel Foucault, 'Technologies of the Self' in Luther H. Martin, Huck Gutman and Patrick H. Hutton (eds.), Technologies of the Self: A Seminar with Michel Foucault, London: Tavistock Publications 1988, 16-49: 18.

${ }^{26}$ Van Dijk, 'Time and Transcultural Technologies of the Self'; Marshall, Political Spiritualities.

27 This distinction between subjectifying and objectifying technologies appears in Foucault's work on confession and examination (cf. M. Foucault, Histoire de la sexualité. La volonté de savoir, Paris: Gallimard 1976; M. Foucault, Surveiller et punir. Naissance de la prison, Paris: Gallimard 1975; N. Fairclough, Discourse and Social Change, Cambridge: Polity Press 1992). 
'leading the fight' against the evil spirit. ${ }^{28}$ This passivity of the possessed person is an indicator for this objectifying process. In this case, deliverance practices do not involve the emergence of a moral subject, but rather correspond to what Foucault calls the 'dividing practices' ('pratiques divisantes') ${ }^{29}$ which divide the subject either within itself ${ }^{30}$ or by separating it from others. ${ }^{31}$

Ritual deliverance practices convey strong normative aspects through the ritual practice of expelling entities that present distinctive features. Thus, characteristics of the expelled entities often point at behaviours that are considered intolerable. Once delivered, the person is not supposed to 'misbehave' again under the influence of the spirit - in which case the deliverance would be considered ineffective. Therefore, taking part in deliverance practices necessarily engages the subject in a transformative process where it is normatively shaped by the spirit expelled.

The ritual presence of spirits taking part in this transformative process carries implications for the construction and transformation of gender roles. Because Pentecostal demonology remains open and can easily integrate new categories of spirits - which is a key element in the 'plasticity' of Pentecostalism, ${ }^{32}$ it can adapt to local gender configurations and social contexts. Thus, variations in Pentecostal demonology or in the associated ritual practices might indicate transformations of the Pentecostal construction of gender.

\section{Spirit Spouses and Mermaids among African Migrants}

The categories of spirits that I will discuss are historically part of several African cosmologies. Their integration into the Pentecostal demonology as 'evil spirits' reflects the broader historical 'translation' process of African cosmologies into Christian discourses by missionaries, in which the demonization of entities from

\footnotetext{
${ }_{28}$ Tough people might choose to ask for deliverance, as in the example above, the ritual itself rarely requires them to be active. Unlike in the Christian technique of confession which is analysed by Foucault as a technology of the self, in deliverance practices, the possessed person is usually asked to remain passive and the main protagonists of the ritual are the pastor and the spirit(s). The body of the possessed person might move and shake, thereby 'manifesting' the spirit(s) that inhabit the body. Thus, the subject is divided into itself (possessing spirit - possessed person) and is therby objectified, which leads us to what Foucault calls 'pratique divisante' (cf. infra).

${ }^{29}$ M. Foucault, 'Pourquoi étudier le pouvoir: la question du sujet' in Hubert Dreyfus and Paul Rabinow (eds.), M. Foucault. Un parcours philosophique, Paris: Gallimard 1984, 297-308.

${ }^{30}$ By identifying the presence of a foreign entity, the spirit, within the person and by expelling it.

${ }^{31}$ We should notice that other practices in the process of Pentecostal conversion might include those moral aspects - whose importance also depends on the kind of Pentecostal denomination. This article will however focus on spirits and deliverance practices.

32 J.-P. Willaime, 'Le pentecôtisme: contours et paradoxes d'un protestantisme émotionnel' in Archives de Sciences sociales des Religions 105 (1999), 5-28; Corten and Marshall-Fratani, 'Introduction'.
}

Religion and Gender vol. 3, no. 1 (2013), pp. 60-75 
African cosmologies represents a key issue. ${ }^{33}$ This process nowadays persists in Pentecostal practices: deliverance also implies the demonization of 'African entities', as we shall see. In this context, the entities borrowed from African cosmologies remain, but they are now labelled as 'evil spirits'. Thus, deliverance practices offered by Pentecostal churches have been interpreted as a way of further living traditional spirit possession, while simultaneously condemning it as a pagan practice. ${ }^{34}$

In the observed Pentecostal deliverance practices, there are several ways by which spirits can be identified. The possessed person's symptoms, their body or social behaviour might indicate the kind of spirit involved. In other cases, like in the example given in the introduction, the name of the spirit is announced before the deliverance and potentially possessed people are invited to come forward to receive prayer. Though the list of existing spirits is open and can incorporate new entities, ${ }^{35}$ some spirits appear to be more recurrent than others. Some of these frequently appearing spirits are considered responsible for gendered misbehaviours, such as in the case of the 'spirit spouse' and the 'mermaid' spirit.

Spirit spouses carry implications for how gender is constructed, especially in the field of relationships. They are supposed to negatively influence marital relationships and offer an explanation for persisting single life and recurrent conflicts in couples. Spirit spouses are said to appear in the dreams of their victims where they have sexual intercourse with them. They are known as jealous and possessive spirits who will try to prevent their victim from living a happy marriage. They are considered responsible for different problems appearing among married couple, including recurrent disputes, lack of sexual interest in one's spouse, and childlessness. They might also have 'children' with their victim, which might be visible when a woman shows pregnancy signs (like a round belly or otherwise unexplained lactation) while she does not expect a baby. Spirit spouses are also said to torment singles, preventing them from finding a spouse.

Spirit spouses are widespread in Pentecostal churches both in the Democratic Republic of the Congo ${ }^{36}$ and in Ghana, ${ }^{37}$ as well as in other West and Central African countries. ${ }^{38}$ However, their existence has preceded Pentecostalism, and spiritual entities similar to spirit spouses were to be found before the

\footnotetext{
${ }_{33}$ B. Meyer, Translating the Devil: Religion and Modernity among the Ewe in Ghana, Edinburgh: University Press 1999.

${ }^{34}$ B. Meyer, 'Les églises pentecôtistes africaines, satan et la dissociation de 'la tradition', Anthropologie et Sociétés 22:1 (1998), 63-84.

35 I encountered around sixty different categories of spirits during my fieldwork.

36 J. Ndaya Tshiteku, ' 'Prendre le bic'. Le combat spirituel congolais et les transformations sociales' PhD thesis, African Studies Centre Leiden, 2008; S. Demart, 'Les territoires de la délivrance. Mises en perspectives historique et plurilocalisée du Réveil congolais (Bruxelles, Kinshasa, Paris, Toulouse)' PhD thesis, Université de Toulouse-Le-Mirail and Université catholique de Louvain-La-Neuve, 2010.

37 B. Meyer 1999, op. cit.; P. Gifford, 2001, op. cit.

${ }^{38} \mathrm{~S}$. Fancello, Les aventuriers du pentecôtisme ghanéen. Nation, conversion et délivrance en Afrique de l'Ouest, Paris: IRD - Karthala 2006; S. Fancello, 'D'un guérisseur à l'autre: diagnostic, délivrance et exorcisme à Bangui' in Bruno Martinelli and J. Bouju (eds.), Sorcellerie et violence en Afrique, Paris: Karthala 2012, 55-84.
} 
appearance of Pentecostal churches, both in the Congo $^{39}$ and in West Africa, for instance among Baoulé (Ivory Coast), where spirit spouses (blolo bla or blolo bian) had spiritually married humans and caused similar problems.

Spirit spouses also appear in African Pentecostal transnational spaces, as I could notice in churches around the Lake Geneva region. They may be expelled during collective ritual practices, as in the Friday night prayer and deliverance session at the Church for the Nations. That evening, most people who received prayer were single women who were hoping to find a husband. In this case, deliverance practices can be interpreted as a technology of gender aiming at making women available for finding a partner - by expelling the jealous spirit spouses that prevent single women from meeting their future husband. This implies both that marriage is highly valued and that long-lasting single life is perceived as an abnormal status. Deliverance practices thus stress the differentiated value attributed to marriage and single life by associating singleness with evil spirits.

Spirit spouses may also be diagnosed as an answer to particular relationship issues. During an interview, a Congolese pastor reported the case of a Congolese woman who married a Swiss man. On several occasions, her husband woke up lying on the floor in the middle of the night, not understanding why he wasn't in the bed anymore. The wife regularly dreamt of having sexual intercourse with a man whose head was hidden. In the morning, she could even see his sperm on her body while taking a shower. The couple disclosed the case to the pastor who identified a spirit spouse that possessed the wife. He explained that this spirit expelled the husband from the marital bed in order to have sexual relationships with the wife. He then proposed a treatment for being delivered from the spirit spouse: three days of fasting, followed by a light meal at 6 p.m. and a long prayer. During three days, the pastor and the wife fasted and in the evening, they prayed and 'took control' over the spirit in order to expel it. Some time later, as the spirit spouse appeared to be returning, the pastor went to the couple's house and prayed there so that the spirit cannot penetrate the house again.

According to the pastor, the spirit spouse is a jealous spirit. For this reason, it was trying to keep the wife for itself by stirring troubles for the relationship. Thus, the wife had become averse to taking good care of her looks. The pastor explained that if the wife was well-dressed and nicely made up, her husband's eyes would fall on her and she would be at the centre of his attention, which the spirit spouse couldn't tolerate. But as long as she neglected herself, her husband would look away from her and feel no attraction.

In this case, deliverance practices can be interpreted as a technology of gender aiming at regulating relationships within married couples. In particular, sexuality issues and the gendered behaviour of the wife are addressed. By expelling the jealous spirit spouse, the wife is supposed to take good care of her looks and to seduce her husband again. This emphasizes the active role and obligations of the wife in the sexual life of the couple. It also carries some normative gender implications relative to body practices, like making up and dressing. Moreover, it stresses the responsibility of the wife towards the sexuality of her husband.

${ }^{39}$ S. Demart, op. cit.

Religion and Gender vol. 3, no. 1 (2013), pp. 60-75 
There is another kind of spirit which appears in Pentecostal churches both in Africa and in Europe and which carries implications for gender construction: the mermaid spirit. In another Congolese church, I listened to the testimony of a woman who married a Swiss man. She gave her testimony in front of the congregation on a Saturday afternoon. She explained that some weeks ago, the doctor diagnosed a problem in her heart. During the same period, she repeatedly had a dream in which she saw a woman intending to harm her. One day, she also had the vision of a feminine figure, which she identified as a mermaid, standing in the door of her bathroom. The woman then asked her pastor and a prophetess for help. While the prophetess confirmed that several spirits were endangering her life, the pastor advised her to pray and went to her house where he poured olive oil in various rooms in the house. The woman spent several nights praying in order to get rid of the spirit. Nonetheless, she was attacked some weeks later and nearly died. While staying at her home, she suddenly felt paralyzed and had a vision in which she was surrounded by people who had died that same moment. There was a book lying on a table on which the names of dying people were listed, but her name did not figure on the book, which meant that God did not want her to die yet. She then began to sing a song which came to her mind and was 'resurrected'. Once she got her wits back, she gazed at her face in a mirror and noticed that it was distorted and her eyelids were blown. She took the oil which she had been given by the pastor and poured it over her face, which instantly improved her appearance.

This testimony stresses the dangerous character of the 'mermaid', a spiritual entity which might even cause death. Its appearance in the door of the bathroom reveals its association with water. However, the mermaid carries other implications that are implicit for the audience of this testimony. In particular, it evokes power associated to wealth, but also seductive power of women. Mermaids appear to be both attractive and deceitful figures. While they initially cause pleasant feelings, their evil powers progressively appear and mermaids eventually turn out to be destructive spirits.

In African cosmologies, entities associated with water can be found in many places around Central and West Africa, including the Democratic Republic of the Congo and Ghana..$^{40}$ They are often known as Mami Wata and are represented as a feminine white body with the tail of a fish. These entities usually present a strong seductive character and are associated with the Western world and its material goods. Like other entities, they have been cast, within Pentecostal cosmology, as evil spirits.

In the Lake Geneva urban region, however, Pentecostal pastors referred to the mermaid spirit essentially in terms of the seductive power of women, and in particular in the context of prostitution. It is said that whenever a mermaid appears in a church, all men gaze at her. The presence of a mermaid is therefore seen as particularly dangerous for the church as they are perceived to be so attractive that it is almost impossible to resist their advances. Mermaid spirits often appear in the dreams of their victims through the presence of water. In fact, mermaid spirits are usually considered as belonging to the broader category

${ }^{40}$ See H.J. Drewal, Sacred Waters: Arts for Mami Wata and Other Divinities in Africa and the Diaspora, Bloomington and Indianapolis: Indiana University Press 2008; B. Jewsiewicki, Mami Wata: La peinture urbaine au Congo, Paris: Gallimard 2003. 
of water spirits, among which other entities like prostitution spirits appear. One pastor told me that he once went to the prostitution area of Geneva to evangelize. On the following Sunday, some women he had met came to the church service and the pastor performed deliverance where he identified the 'spirit of prostitution', which he considers to be the same spirit as the mermaid spirit. Those spirits are considered responsible for sexual misbehaviours associated with excessive attractiveness or with prostitution. Women who are possessed by a mermaid spirit might also have problems in finding a husband, despite their attractiveness.

In the discussed cases involving mermaid spirits, deliverance practices can be interpreted as a technology of gender aiming at controlling and restraining sexuality and seduction by women, in particular when it involves financial or material compensation. By denouncing mermaids in the churches, pastors warn women against taking advantage of seductive behaviours to subvert monogamous gender order or to contest established authority in the church. Mermaids typically apply to unmarried women with multiple partners, which might also recall the practice of the 'deuxième bureau', as we shall see in the next section. Deliverance practices thus enhance monogamy principles and associate excessive attractiveness and sexuality outside married couples with evil spirits.

\section{Negotiation of Gender Roles by Ritual Technologies in Transnational Spaces}

I will now discuss the implications of spirits such as mermaids and spirit spouses on the construction of gender in Pentecostal transnational spaces. As I mentioned, mermaids and spirit spouses have their roots in African Pentecostalism where they echo former categories of spiritual entities (like Mami Wata or blolo bla). The increasing popularity of deliverance practices within African Pentecostalism in the 1990s has given those spirits, along with others, a prominent role in Pentecostal ritual practices. Mermaids and spirit spouses 'travelled' to Europe, carried by Pentecostal migrants, where they continued to be mentioned as a spiritual cause of misfortune or gendered disorder. But the general gender context has been changed by the migration process, and the role of spirits and rituals as technologies of gender must be considered within this new general gender context. As I will show, mermaids and spirit spouses sometimes contribute to a 'negotiation' of gender roles that question gender configurations both in Africa and in Europe.

Pentecostal discourses highly value marriage as the realization of God's plan for men and women. However, African migrants happen to be mostly unmarried. According to available statistics, more than half of the Sub-Saharan African population living in Switzerland is not married..$^{41}$ This not only reflects the fact that African migrants are often young, but also that migration trajectories tend to delay marriage. Thus, some migrants find themselves single at an age where they would probably have been married, had they not migrated. Many migrants visit church services with the hope of finding a suitable partner. Several

${ }^{41}$ Efionayi-Mäder et al., 2011, op. cit.

Religion and Gender vol. 3, no. 1 (2013), pp. 60-75 
couples I encountered have met in the context of a Pentecostal church. Attending a Pentecostal church can therefore be considered a matrimonial strategy for unmarried migrants and pastors sometimes officiate as go-between for singles in quest of a partner. In the case of persisting single life, deliverance offers a way of releasing stresses between their aspirations for marriage and their single status by casting out the responsible spirit. With this ritual practice, single people show that, although their single status impedes them from meeting the gendered ideal of masculinity or femininity in Pentecostal terms, they are determined to resolve this situation.

In the case of married African couples, rituals can also play an important role in their relationship. For one thing, the migration process may induce changes in traditional gender roles. One such reversal has to do with the opportunities offered to men and to women in terms of employment and income opportunities. While among African migrants who live in Switzerland, men are more qualified than women, they both experience a similarly high rate of unemployment. Moreover, whichever employment a qualified man may find, it seldom meets his qualifications. Therefore, the migratory setting tends to afflict men with greater downward social mobility than women. For some Pentecostal migrants, the main income source was earned by the wife, leading to frequent relationship problems that are dealt with in the context of church services. ${ }^{42}$ Pentecostal ritual practices open a space to address the reconfiguration of gender roles due to the migration context. On the one hand, Pentecostal discourses tend to positively stress the role of women as wives, mothers as well as businesswomen, therefore giving legitimacy to their function as breadwinner. On the other hand, they warn women against using their income to gain authority over their husbands and stress the fact that this money must be available for their husband as well. Pentecostal discourses constantly stress the role of the wife in taking care of their husband and meeting their needs, while husbands are depicted as heads of the family. ${ }^{43}$ These discourses convey the idea that the ideals of masculinity and femininity are not endangered by a change in the balance of income and the downward social mobility of men, while conferring legitimacy on this changing configuration of gender roles.

While questions of authority and power relations between genders are explicitly addressed in Pentecostal discourses, questions of sexuality and fertility are more often approached through deliverance practices. Mermaids and spirit spouses address the questions of sexual availability, infidelity, seduction and fertility within or outside the couple. Spirit spouses also stress the importance for women to be attractive for their husbands and to be sexually available for them. On the other hand, mermaid spirits warn women against misusing their seductive power to attract men.

\footnotetext{
42 In the case of Congolese migrants, the ideal of masculinity relies on the ability of the husband to provide an income that allows his wife to 'dress up properly'. Similar tensions arise in the Democratic Republic of Congo where women have often been responsible for providing income since the 1990s. However, the ideal of masculinity has largely remained unchanged (Ndaya Tshiteku, 2008, op. cit.).

${ }^{43}$ In African Pentecostal settings, this might also mean taking care of their wives and meeting the need of their family. See A.S. van Klinken, 'Male Headship as Male Agency: An Alternative Understanding of a 'Patriarchal' African Pentecostal Discourse on Masculinity' in Religion and Gender 1:1 (2011), 104-124.
} 
Deliverance unequally applies to men and women: most of the people who are delivered in church services are women. This observation carries implications in terms of gender construction. It is important to note that although spirits theoretically attack both men and women, in practice, women constitute the overwhelming majority of people looking for deliverance in the Lake Geneva urban region. ${ }^{44}$ By contrast, pastors who pray for deliverance are mainly men. As spirits are responsible for negatively valued behaviours, discerning their presence and casting them out involves a normative limitation of the spectrum of gendered behaviours for the possessed person. But because women are in practice more often possessed - or at least more often seeking deliverance than men, this control over gendered behaviours through deliverance practices applies mainly to women.

So, the recourse to mermaids and spirit spouses tends to promote a gender model, where the responsibility for seduction, sexual relationships and fertility lies in the women and exonerates men from their behaviour. For instance, masculine infidelity might be attributed to the possession of a woman by a spirit, both in the case of mermaids and spirit spouses. Masculine infidelity can be attributed to the excessive attractive power of a woman possessed by a mermaid spirit to which men cannot resist. Such infidelity can also be attributed to the lack of attractiveness of a wife possessed by a spirit spouse that would lead the man to avert his gaze from her. In this case, mermaids and spirit spouses tend to formally stress monogamy principles while allowing for the maintenance of multiple relationships, especially for men, without necessarily being stigmatized for it. The responsibility for these multiple relationships is attributed to women's possession by spirits and not to men's behaviour.

Thus, Pentecostal practices meet the broader issue of masculine selfaccomplishment. In some African regions, multiple relationships are important for the ideal of masculinity, and love affairs contribute to a man's status. For instance, having a 'deuxième bureau' (second office) means to have a long-lasting relationship with an unmarried woman, which also implies supporting her financially. This practice was widespread in West and Central African regions, for instance in Zaire (under the Mobutu regime) or in Ivory Coast in the 1980s among urban civil servants and employees with a regular income. ${ }^{45}$ Political and economic crises, however, made it increasingly difficult for a man to be able to support a 'deuxième bureau'. Still, the association between masculine status production and multiple relationships remained.

Pentecostal ritual practices negotiate a turn in this ideal of masculinity, since faithfulness is formally promoted and the possibility of multiple sexual partners is formally rejected. In the Lake Geneva region, the practice of 'deuxième bureau', which found a new expression among the Congolese diaspora, ${ }^{46}$ is sometimes mentioned and condemned in African churches. But behind this apparently clear statement, deliverance practices tend to forsake the idea of an individual

\footnotetext{
${ }^{44}$ The same observation has been reported in the West African context (Gifford 2001, op. cit.; Fancello 2006, op. cit.).

${ }^{45}$ B. Lacombe, 'Les unions informelles en Afrique au Sud du Sahara: I'exemple du deuxième bureau congolais' in Genus 43:1-2 (1987), 151-164.

${ }^{46}$ Julie Ndaya mentions that the 'deuxième bureau' found a new expression among the Congolese diaspora under the name 'système des deux ba bord' where men have relationships with two women (J. Ndaya Tshiteku, op. cit.).
}

Religion and Gender vol. 3, no. 1 (2013), pp. 60-75 
responsibility for one's sexual behaviour. It offers a space for the negotiation of this new ethos ${ }^{47}$ where women are largely held responsible for the sexual behaviour of their husbands or lovers and where the inappropriate behaviour of men can also be attributed to the women through their possession by spirits. ${ }^{48}$ Deliverance practices imply a gender causal attribution of unfaithfulness where responsibility for the sexual behaviour of men and women alike tends to be attributed to women. This case shows how deliverance technologies ritually deal with changes in gender roles and offer a space to negotiate tensions between conflicting gender models. ${ }^{49}$

However, in the European context, deliverance might lose part of its importance in Pentecostal practices. Several observers agree on the fact that, in Europe, Pentecostal deliverance tends to take a more euphemized form where trance becomes more marginal in deliverance practices. ${ }^{50}$ Deliverance increasingly borrows categories from the psychological realm and forsakes some bodily practices that were central in the African context. This tendency could be linked with lower acceptance of trance practices in Europe. In the Lake Geneva urban area, I also observed that some pastors contest the presence of spirits in the European migratory context. According to these Pentecostal leaders, spirit spouses are too easily mobilized to explain marital problems. They reject these 'African' spirits which, they suggest, 'should remain in Africa'. Though this trend would deserve a deeper study, questioning the existence of spirit spouses expresses a critical stance towards deliverance as a technology of gender in a migration context. This rejection of deliverance might also imply a contestation of gender causal attribution for relationship problems.

\section{Conclusion}

In this article, I discussed the role of ritual practices in the construction of gender. I focused on deliverance practices, where spirits are expelled from a person's

\footnotetext{
${ }^{47}$ The ethos is associated to the social ideal of self-accomplishment, as suggested by Yvan Droz (Y. Droz, Migrations kikuyus: Des pratiques sociales à l'imaginaire, Neuchâtel: Editions de I'Institut d'ethnologie 1999), which is also gendered.

${ }^{48}$ This possession might in turn be attributed to a lack of prayer by the wife. This configuration of gender causal attribution of unfaithfulness can also be found in West Africa, cf. S. Fancello, 'Pouvoirs et protection des femmes dans les Églises pentecôtistes africaines' in Revista de Estudos da Religião 3 (2005), 78-98.

49 In this article, I concentrate on deliverance rituals. However, other aspects of this new Pentecostal gender ethos could be mentionned, which are not limited to sexual behaviours and appear in other Pentecostal practices as well (see J.E. Soothill, Gender, Social Change and Spiritual Power: Charismatic Christianity in Ghana, Leiden, Boston: Brill 2007; M. Maskens, 'Cheminer avec Dieu'. Pentecôtisme et migration à Bruxelles, Thèse de doctorat soutenue à I'Université Libre de Bruxelles, 2010; J. Rey, Migrations africaines et pentecôtisme en Suisse: des dispositifs rituels au commerce de l'onction, Phd thesis in Anthropology and Sociology, Graduate Institute in International and Development Studies, Geneva, 2013).

${ }^{50}$ See R. van Dijk, 2001, op. cit. or A. Mary, 'Christianisme prophétique et Nations Célestes. Le combat spirituel pour la purification du monde' in S. Fancello and A. Mary (eds.), Chrétiens africains en Europe: Pentecôtismes, prophétismes et politique des nations, Paris: Karthala 2010, 127-153.
} 
body. I argued that these spirits, which are held responsible for the misfortune of their victims, contribute to the construction of gender as they carry negative values against which gender models are constructed. By expelling these spirits, ritual deliverance practices aim at producing subjects that follow a Pentecostal gender model. They can therefore be considered as a 'technology of gender'.

In Pentecostal churches founded by Congolese or Ghanaian pastors in the Lake Geneva region, I identified two categories of spirit that are deeply involved in the construction of gender norms in deliverance rituals: spirit spouses and mermaid spirits. Spirit spouses regulate gendered behaviours within married couples in terms of seduction, sexual attraction and intercourse. Mermaid spirits also regulate gendered behaviours between men and women outside couples. In both cases, deliverance mainly applies to women, which suggests that women constitute the place where the problem lies and where it can be tackled. Deliverance practices tend therefore to attribute responsibility to women and exonerate men from their behaviour.

By this technology of gender, deliverance rituals address the issue of normativity and deviance in gender roles. On the one hand, deviance is attributed to spirits, which are held responsible for misfortune and for behaviours that transgress gender norms. On the other hand, naming the spirits and the undesired consequences of their presence establishes or reinforces gender norms. Pentecostal deliverance practices also contribute to edify gender norms in labelling people whose behaviours transgress those norms as 'possessed' by these spirit which is negatively valued. Deliverance from these spirits can therefore be interpreted as a normalisation process, both in the sense of establishing gender norms and in the sense of (re-)integrating people transgressing these norms.

Deliverance as a technology of gender not only establishes norms and tackles deviance, but also opens a space for negotiating stress between conflicting gender roles. As long as deliverance is practiced, it offers a space for alternative ethos to coexist. For example, exclusive marital and multiple sexual partnerships are two possible forms of masculine ethos addressed by deliverance practices. While the former is valued and the latter condemned in Pentecostal discourses, deliverance practices still offer a space for this alternative ethos by forsaking the idea of an individual responsibility for one's sexual behaviour.

The mobilization of African categories of spirits, like spirit spouses and mermaids, underlines the importance of the transnational context and points to gender configurations in Africa. Nevertheless, the negotiation of gender in a migration context also takes the local setting into account. Migrants evaluate gender practices both in Europe and in Africa and negotiate gender relationships, gender norms and gendered behaviours through Pentecostal ritual means. Deliverance practices and Pentecostal discourses address relationship issues (e.g. in the field of sexuality or fertility) and transformations in gender configurations (due to economic changes and the confrontation with other gender models in Europe). They enhance a particular Pentecostal gendered ethos, while leaving a space for alternative gender models to coexist - in spite of their rejection - by attributing gender deviance to spirits. In this process, Pentecostal churches contribute to a redefinition of masculine and feminine ethos within transnational spaces. 